SHORT REPORT

\title{
Emergency contraception. Has over the counter availability reduced attendances at emergency departments?
}

\author{
M Kerins, E Maguire, D K Fahey, E Glucksman
}

Emerg Med J 2004;21:67-68

Legislation introduced in January 2001 has meant that progestogen only contraception is now available without prescription for women aged 16 years and over. Patient records of two emergency departments in the South East Thames region between 2000 and 2001 were reviewed and it was found that there was a $52 \%$ reduction in the number of women attending these emergency departments with requests for emergency contraception. These findings suggest that the legislation has meant that more women are getting their emergency contraception without prescription from pharmacies as compared with emergency departments.

n January 2001 legislation amended the Prescription Only Medicines Order resulting in progestogen only contraception now being available without prescription for women aged 16 years and over. ${ }^{1}$ This means that local pharmacies provide an additional point of access to emergency contraception for those women who can afford the $£ 20$ charge. The product that is available to buy is $0.75 \mathrm{mg}$ levonorgestrel, which is taken twice, with the two doses separated by 12 hours and the first dose taken within 72 hours of intercourse. This progestogen only regimen is now preferred because it is more effective than the Yuzpe regimen and causes less nausea and vomiting. ${ }^{2}$

The changes described above have been welcomed by many emergency physicians who feel that they have led to fewer requests for emergency contraception at busy emergency departments. To discover if this had actually happened we tested the hypothesis that legislation changing emergency contraception availability from prescription only to over the counter has made no difference to the proportion of women attending emergency department(s) for emergency contraception.

\section{METHODS}

We retrospectively searched the electronic patient record systems (Footman-Walker and Remass) for patients requesting emergency contraception at two emergency departments in the South East Thames region (King's College Hospital $(\mathrm{KCH})$ in London and Bromley Hospital (BH) in Kent) between 1 April and 30 June in 2000 and 2001. In cases where the reason for attendance was unclear the written case notes were reviewed. Data were collected on patient's age, GP registration, and whether or not the patient was prescribed emergency contraception after her request.

Possible confounding factors identified but found to be insignificant were a change in the proportion of patients

*Details on how these confounders were assessed are available on request from the authors. registered with a GP, a change in the computer systems at the emergency departments over the duration of the study, a change in local pharmacy or family planning clinic opening hours in the areas, and an increase in waiting time to be seen by a doctor at either department in 2001 compared with $2000^{*}$.

\section{RESULTS}

Table 1 shows the total number of attendances at both emergency departments for the study periods and the number accounted for by those women seeking emergency contraception. We have shown that there were a statistically greater proportion of attendances requesting emergency contraception in $\mathrm{KCH}$ and $\mathrm{BH}$ in 2000 compared with 2001 $(p<0.001, \alpha=0.05)$. This reflects a $52 \%$ decrease in requests.

Personal communication with the manufacturers of levonelle, Schering Health, showed that 33\% of total emergency contraception sales in 2001 were accounted for by over the counter sales. In addition the total sales of emergency contraception in 2001 for the UK showed an increase of $20.7 \%$ compared with 2000 (personal communication, Schering Health, December 2002).

\section{DISCUSSION}

The change in legislation that resulted in re-classification of progestogen only contraception from prescription only to over the counter availability has led to a significant reduction in attendances at our emergency departments for emergency contraception. Our findings support a recent report in the $B M J$ that found that the number of women obtaining emergency contraception from family planning clinics decreased by $15 \%$ in 2001 compared with $2000 .^{3}$

The results of our study suggest that despite an overall increase in sales of emergency contraception in 2001 compared with 2000 the change in legislation has resulted in a decrease in the burden of health care for emergency departments. However, some authors feel that the increased availability of emergency contraception will lead to a decrease in the use of barrier methods and subsequent higher rates of sexually transmitted diseases. ${ }^{4}$

Although the results of our study show that direct pharmacy provision leads to a $52 \%$ decrease in emergency

Table 1 Change in attendances at $\mathrm{KCH}$ and $\mathrm{BH}$ emergency departments from 2000 to 2001

\begin{tabular}{lll}
\hline & $\begin{array}{l}\text { Total attendances } \\
\text { at } \mathrm{KCH} \text { and } \mathrm{BH}\end{array}$ & $\begin{array}{l}\text { Number requesting EC } \\
\text { at } \mathrm{KCH} \& \mathrm{BH}\end{array}$ \\
\hline $\begin{array}{l}\text { 1 Apr-30 Jun } \\
2000\end{array}$ & 36915 & $237(\mathrm{KCH} 72)(\mathrm{BH} 165)$ \\
$1 \mathrm{Apr}-30$ Jun & 35985 & $110(25 \mathrm{KCH})(85 \mathrm{BH})$ \\
2001 & & \\
\hline
\end{tabular}

EC, emergency contraception. 
department attendances for emergency contraception, there remains room for further reduction. Tackling other potential barriers such as high cost, limited pharmacy opening hours, and lack of patient awareness is likely to be associated with an even greater decrease in the number of attendances.

\section{Authors' affiliations}

M Kerins, E Glucksman, Department of Emergency Medicine, King's College Hospital, London, UK

E Maguire, Department of Emergency Medicine, Bromley Hospital, Bromley, UK

D K Fahey, Public Health Department, Camden Primary Care Trust, London, UK
Correspondence to: $\operatorname{Dr} M$ Kerins, Department of Emergency Medicine, King's College Hospital, Denmark Hill, London SE5 9RS, UK; mkerins_fahey@hotmail.com

Accepted for publication 3 June 2003

\section{REFERENCES}

1 Department of Health. Wider availability of emergency contraception, 2001 http://www.doh.gov.uk/ehc/index.htm

2 Task Force on Postovulatory Methods of Fertility Regulation. Randomised controlled trial of levonorgestrel versus the Yuzpe regimen of combined oral contraceptives for emergency contraception. Lancet 1998;352:428-33.

3 Lancucki L, Saberton I. NHS Contraceptive Services, England. BMJ 2002;325:986.

4 Gold M. Emergency contraception. Adolescent Medicine: State of the Art Reviews 1997;8:455-63.

\section{Clinical Evidence - Call for contributors}

Clinical Evidence is a regularly updated evidence based journal available worldwide both as a paper version and on the internet. Clinical Evidence needs to recruit a number of new contributors. Contributors are health care professionals or epidemiologists with experience in evidence based medicine and the ability to write in a concise and structured way.

\section{Currently, we are interested in finding contributors with an interest in} the following clinical areas:

Altitude sickness; Autism; Basal cell carcinoma; Breast feeding; Carbon monoxide poisoning; Cervical cancer; Cystic fibrosis; Ectopic pregnancy; Grief/bereavement; Halitosis; Hodgkins disease; Infectious mononucleosis (glandular fever); Kidney stones; Malignant melanoma (metastatic); Mesothelioma; Myeloma; Ovarian cyst; Pancreatitis (acute); Pancreatitis (chronic); Polymyalgia rheumatica; Post-partum haemorrhage; Pulmonary embolism; Recurrent miscarriage; Repetitive strain injury; Scoliosis; Seasonal affective disorder; Squint; Systemic lupus erythematosus; Testicular cancer; Varicocele; Viral meningitis; Vitiligo

However, we are always looking for others, so do not let this list discourage you.

\section{Being a contributor involves:}

- Appraising the results of literature searches (performed by our Information Specialists) to identify high quality evidence for inclusion in the journal.

- Writing to a highly structured template (about 2000-3000 words), using evidence from selected studies, within 6-8 weeks of receiving the literature search results.

- Working with Clinical Evidence Editors to ensure that the text meets rigorous epidemiological and style standards.

- Updating the text every eight months to incorporate new evidence.

- Expanding the topic to include new questions once every 12-18 months.

If you would like to become a contributor for Clinical Evidence or require more information about what this involves please send your contact details and a copy of your CV, clearly stating the clinical area you are interested in, to Claire Folkes (cfolkes@bmigroup.com).

\section{Call for peer reviewers}

Clinical Evidence also needs to recruit a number of new peer reviewers specifically with an interest in the clinical areas stated above, and also others related to general practice. Peer reviewers are health care professionals or epidemiologists with experience in evidence based medicine. As a peer reviewer you would be asked for your views on the clinical relevance, validity, and accessibility of specific topics within the journal, and their usefulness to the intended audience (international generalists and health care professionals, possibly with limited statistical knowledge). Topics are usually 2000-3000 words in length and we would ask you to review between 2-5 topics per year. The peer review process takes place throughout the year, and our turnaround time for each review is ideally 10-14 days.

If you are interested in becoming a peer reviewer for Clinical Evidence, please complete the peer review questionnaire at www.clinicalevidence.com or contact Claire Folkes(cfolkes@bmigroup.com). 